\title{
Effect of Islamic Corporate Governance on the Relationship Between Pressure, Opportunity, Rationalization, Capability and Banking Fraud in Selected Banks in Nigeria: A Pilot Test
}

\author{
Ali D. Yusuf, Umar Ahmad, Mohammed Shahril Bin Ahmad \\ Islamic Business School, College of Business, University Utara Malaysia, Sintok, Kedah State Malaysia \\ Email address: \\ aliyusufdanladi@gmail.com (A. D. Yusuf), ahmad.u2005@gmail.com (U. Ahmad), shahril@uum.edu.my (M. S. B. Ahmad)
}

\section{To cite this article:}

Ali D. Yusuf, Umar Ahmad, Mohammed Shahril Bin Ahmad. Effect of Islamic Corporate Governance on the Relationship Between Pressure, Opportunity, Rationalization, Capability and Banking Fraud in Selected Banks in Nigeria: A Pilot Test. International Journal of Finance and Banking Research. Vol. 2, No. 5, 2016, pp. 163-166. doi: 10.11648/j.ijfbr.20160205.11

Received: July 29, 2016; Accepted: August 4, 2016; Published: August 16, 2016

\begin{abstract}
The aim of this paper is to examine a few sample data on the effect of Islamic corporate governance on the relationship between pressure, opportunity, rationalization, capability and banking fraud in selected banks in Nigeria. Thus, instruments such as content and face validity, reliability and the data normality were also examined based on the on revised version by an expert, a few data were analyzed using the statistical software SPSS version 17. The result reveals that the instruments are reliable and the data for pilot study show evidence of rational normality.
\end{abstract}

Keywords: Islamic Corporate Governance, Pressure, Opportunity, Rationalization, Capability, Banking Fraud and Pilot Test

\section{Introduction}

Fraud is the one of the numerous enemies of the business world. (Adewumi, 1986; Idah, 2004). The higher incidence of fraud within the banking sector has become a source of worry and the solution to it must be found (Nigeria Deposit Insurance Corporation (NDIC), 2003). This is in view of the large sums of money involved and its adverse implication on the world economies. Fraud at whatever level reduces the assets and increases the liability of any organization (NDIC, 2012). In the case of banks, this may result in the loss of potential customers or crisis of confidence of banking by the public and in the long run ended up in another failed bank situation, as much as various measures have been taken to minimize the incidence of fraud, it still rises day by day. This is because fraudsters always device tactical ways of committing fraud. This has become a point of attention within the banking sector (Central Bank of Nigeria, 2013).

The problem of financial fraud is more pronounced in the financial sector than in other industries (Joyner, 2011). According to Association of Certified Fraud Examiners (ACFE) report 2012, it is estimated that a typical organization loses $5 \%$ of its revenues to fraud each year and cumulative annual fraud loss globally during 2011 amounted to more than
\$3.5 trillion. For instance, 8.1 million Americans were victimized by identity fraud, a crime amounting to $\$ 45$ billion USD (Racheal and May, 2008). Card fraud losses cost the UK economy US\$767 million in 2006. Credit card fraud accounts for the biggest cut of the $\$ 600$ million that airlines lose each year globally, according to Deloitte research. Enron, WorldCom and more recently, the Libor manipulation scandals, have caused major upheaval in western nations and their impact has been felt not only in the individual institutions or countries but across the global financial system (Chakrabarty, 2013).

In relation to Nigeria, the country is relatively oil rich nation with oil revenue account for $90 \%$ of the foreign exchange earnings CBN (2010). But Nigerian's basic social indicators place it among the 20 poorest countries in the world (Transparency International, 2012). These are due to several factors such as economic mismanagement, corruption, fraud and lack of accountability leads to poor economic performance and higher poverty among the Nigerian population Nigeria. According to Transparency International report (2013), Nigeria is ranked among the most corrupted country in the world. According to Transparency International report (2013), Nigeria was ranked at 144 among the 177 countries of the world. Shehu (2006), the resultant effect of 
these abuses was that the legal, financial and social institutions responsible for the orderly existence of the society have become vulnerable and carried by vices such as corruption, greed, economic mismanagement and financial crime, which all having negative serious implication on social welfare of Nigerian society Financial Action Tax force (FATF) a supervisory agency with IMF.

Recent events in Nigeria is so disturbing on how government agencies continue to defraud the nation commonwealth, a development economist and financial analyst, $\mathrm{Mr}$ Odilim Enwegbara recently argue how government agencies were allowed to remit $80 \%$ of operating surplus to consolidating revenue fund Account, they ended up driving the operating cost so high, it allows to declare close to zero operating surplus, and as a result $80 \%$ of their to government treasury close to zero naira (Okeke, 2013). The adverse effect of fraud hinders the progress and services provided by these banks or organization.

In order to cure this sickness, the policy makers and the banking sector put in place mechanism to detect and prevent financial fraud. For instance, in addition, Nigerian Central Bank (CBN), and Nigerian Deposit Insurance Corporation (NDIC) issued several legislation and decrees to strengthen corporate governance and improve on transparency and accountability. The available evidences have shown that conventional approaches being used in curtailing fraud seems to be ineffective and it is for that reason, an alternative approach in form of corporate governance model should be put in place.

There is no doubt that adopting Islamic banking with its corporate governance model can cure financial fraud in banking sector in Nigeria. Yet, there are hardly empirical studies, particularly in Kano State in Nigeria that examines the perception of customers on prevalence of financial fraud in banking sector and moderating effect of Islamic corporate governance. In addition to the best of my knowledge, there is no study that has been conducted to examine the role of Islamic corporate governance model in Islamic banks in eradicating financial fraud. Therefore, this study attempts to fill this research gap.

To this end, the paper presents the result of pilot test with regard the effect of Islamic corporate governance on the relationship between pressure, opportunity, rationalization, capability and banking fraud in selected banks in Nigeria.

\section{Research Methodology}

\subsection{Introduction}

Knowing to the information that this study is a pilot test of ongoing research small samples of Islamic banking and conventional banking industries were randomly selected. This is in accordance's with the commendation by Malhotra (2008) that the sample size for pre-test is usually few, starting from 15-30 respondents but it be increased substantially if the test involves several stages. Hence, a total of 30 copies of questionnaires were individually circulated and 24 were completed. Sekaran and Bougie (2010) specified that the most accepted a test of interitem uniformity reliability is Cronbach's alpha coefficient. Thus, the Cronbach alpha test is engaged, in this research to determine internal uniformity of the tool. The data were analyzed using SPSS version 18 for windows. Before the delivery of the questionnaires, the draft was firstly submitted to experts and also to the distinctive respondent for look and content validity. The entire procedure was finished between the periods of three weeks in the months June. 2016/ July. 2016.

\subsection{Instrumentation and Measurement of Variables}

A well prepared questionnaire comprising of closed ended multiple choice-questions were used for the study. Given that mainly of the items in the questionnaire are besieged to measuring the respondents' perceptions. Thus, Likert-type scale is regarded as the most appropriate and reliable (Alreck $\&$ Settle, 1995; Miller, 1991). The mostly rating scales for measuring the latent construct in social science research will be used in the study (Churchill \& Peter 1984). The research will structure all constructs in the measuring instrument to use 5-point Likert type of scale, including the independent, mediating and the dependent variables.Despite some other literatures have argued about the benefits inherent in 5-point Likert type of scale, but still a 7-point Likert scale is said to provide detailed feedback and also not subjecting the respondents into any undue cognitive burden (Hair et al.,2010; Cavana et al., 2001; Churchill \& Peter 1984). Thus, to achieve a better optimal result in information processing and scale, reliability, 5-point Likert scales is said to be efficient (Churchill \&Peter 1984).By Krosnick and Fabrigar (1997), that forcing participants to act in a particular direction could result in an increase of measurement error. Krosnick and Fabrigar (1997) also found that the effect of interviewer bias tends to decrease and data quality tends to increase when a midpoint is included in a scale. This will give the respondents independent of expressing their feelings.

The key factors contained in the study are: Pressure, opportunity, rationalization, capability, Islamic corporate governance and financial frauds in banks. All the constructs/variables are uni-dimensional Section 1: consists of a set ofseventeen questions that seek to measure the level of pressure towards the attainment of bank frauds. Section 2: consists of eleven questions targeted at measuring the opportunity in the bankingindustry. Section 3: is comprised up of a total of twenty five questions which attempt to measure the extent of rationalization as perceived by the respondents. Section 4: contains five items that are directed to measure the capability as perceived by the respondents. Section 5: Islamic corporate governance. Finally, section 6: Consists of questions about the financial fraud of the as perceived by the respondents. The significant items that will be used in answering the research questions areincluded in the questionnaire. Furthermore, responsive questionnaire are not included in order to obtain high response rate (Sekaran \& Bougie, 2010). 


\section{Results of Validity and Reliability Tests}

\subsection{Content and Face Validity}

In order to make sure that the determine consists of an sufficient and representative position of items that spout a exacting idea, this involves a orderly appraisal of the scale's ability to determine what is theoretical to measure. Thus, content validity entails requiring a few samples of characteristic respondents and/or teamof specialist to make judgment on the appropriateness of the items chosen to determine a variable (Hair, Money, Samouel \& Page, 2007; Hair, Black, Babin, Anderson, Tathan, 2010; Sekaran and Bougie, 2010).Therefore, a sample of the instrument of this paper was circulated to specialist in order to get outcome regarding the appropriateness, comfortable, and sufficiency of the items that are planned to determine the constructs under examination. Similarly, some Ph.D. candidates who are well -known with the context of the study were also contacted to make sure the clearness of the instrument. a number of observations were re-worded/rephrase in order to determine the constructs properly and also to be clear to the possible respondents. This process of seeking for specialist opinion was completed within three-week period. Following delightful into consideration of the observation by the specialist, then the researcher came up an enhanced version of the instrument which was eventually administered for the pilot study.

\subsection{Reliability Test}

A part of the content and face validity different kind of reliability tests are frequently employed, therefore, the common method used by researchers is the internal consistency reliability test (Litwin, 1995). It is refer as the degree to which items "dangle jointly as a set" andare able of autonomously measuring the identical concept to the degree that the items are related with one another. Thus, Sekaran and Bougie (2010) state that the most accepted tests of inter-item consistency reliability are Cronbach's alpha coefficient. Therefore, the Cronbach alpha test is employed in this study to determine internal consistency of the mechanism. After administration the data using SPSS version 17 for windows, the result reveals that all the measures have high reliability criteria ranging from 0.741 to 0.959 . This is in line with the yardstick that an instrument with coefficient of 0.60 is considered to have an average reliability while the coefficient of 0.70 and above shows that the instrument has a high reliability standard (Hair, Black, Babin, Anderson, \& Tatham, 2006, 2010; Nunally,1967; Sekaran \& Bougie, 2010) and a coefficient of 0.50 as supportive (Nunally, 1967). Furthermore, Hair, Money, Samouel, and Page (2007) view that researcher usually regard that an alpha value of 0.70 as at least, however, lower coefficients may be acceptable. Table1 shows the digest of the reliability results. It may perhaps be seen from the table that the result of pilot study shows that Cronbach's alpha values for the variable under examination are all above 0.70 . Accordingly, given the recognized yardstick of 0.70 all the variables are reliable.

\subsection{Data Distribution}

Generally the inferential statistical methods necessitate the completion of normality hypothesis (Pallant, 2001; Tabacknich \& Fidell, 2007). Normal data is the one that is balanced, bell-shape, with the maximum frequency of scores in the middle and smaller distribution towards the extreme ends. Normality can be measured by using the values of skewness and kurtosis. While the skewness deal with the symmetry, kurtosis shows the extentto which the data is the peak or flat (Tabacknich \& Fidell, 2007). Therefore values of skewness and kurtosis the data can be regarded as rationally normal.

\section{Conclusion}

The Objective of this study is to determine the pilot test; pilot study is the validity and reliability of the instrument of a continuous project in homework for the large scale study. Thus, the end of this study is tied to its aims which are mainly statistical in nature at this point. The implication of the constructs would be fully exposed after the main study is carried out. The study brings the few scale data that were collected during the pilot study. Content and face validity were carried out which consequently led consideration to specialist view to attain the revised version of the instruments. Moreover, the inter item reliability test indicated that all the items were reliable with Cronbach Alpha well above the yardstick of 0.70; by this means no items were deleted. Finally, normality test using skewness and kurtosis shows that the data as an entire is rationally normal.

Table 1. Summary of Pilot Test.

\begin{tabular}{llll}
\hline S/No. & Variables & Items & Cronbach's Alpha \\
\hline 1. & Pressure & 17 & 0.864 \\
2. & Opportunity & 11 & 0.899 \\
3 & Rationalization & 5 & 0.878 \\
4 & Capability & 5 & 0.741 \\
5 & Islamic Corporate Governance & 13 & 0.845 \\
6 & Financial Fraud & 5 & 0.959 \\
\hline
\end{tabular}

\section{References}

[1] Adewumi, W. (1986), Fraud in Banks. Landmark Publications Ltd, Lagos.

[2] Alreck, P.L. \& Settle, R.B. (1995). The survey research handbook. Second edition, Boston: Irwin.

[3] Association of Certified Fraud Examiners annual reports (2012).

[4] Cavana, R., Delahaye, B. L., \& Sekaran, U. (2001).Applied Business Research: Qualitative and Quantitative Methods. Singapore: Markono Print Media Ltd.

[5] Chakrabarty, K. C. (2013). Fraud in the banking sector: cause, concern \& cures. National conference on financial fraud organizes by ASSCH, New Delhi. 
[6] Churchill, G. A., \& Peter, J. P. (1984). Research design effects on the reliability of rating scales: A meta-analysis. Journal of Marketing Research, 21(4), 360-375.

[7] Central Bank of Nigeria (2010) Annual Report.

[8] Central Bank of Nigeria (2013) Annual Report.

[9] Hair, Jr., J. F., Money, A. H., Samouel, P. \& Page, M. (2007). Research methods for business. Chichester: John Willey \& Sons Ltd.

[10] Hair, J. F., Jr., Black, W. C., Babin, B. J., Andersen, R. E., \& Tatham, R. L.(2010). Mutilvariate data analysis (7th ed.). Upper Saddle River, NJ:Pearson Prentice Hall.

[11] John, G.(2011). Law \& Morality.

[12] Krosnick, J.A. \& Fabrigar, L.R. (1997). Designing rating scales for effective measurement in surveys. In L. Lyberg, P. Biemer, M. Collins, E. De Leeuw, C. Dippo, N. Schwarz and D.Trewin (Eds.), Survey measurement and process quality. New York: John Wiley \& Sons, Inc.

[13] Litwin, M.S. (1995). How to measure survey reliability and validity. Thousand Oaks, California: Sage Publication.

[14] Malhotra, N.K. (2008). Essentials of marketing: An applied orientation (2nd ed.). Australia: Pearson Education

[15] Miller, C.D. (1991). Handbook of research design and social measurement. Newbury Park, California: Sage publications.
[16] Nigerian Deposit insurance corporation annual report and statements of accounts various issues $(2003,2012)$.

[17] Okeke, V.O.S \& Uche, G.O (2012). The political economy of the propose Islamic banking and finance in Nigeria prospect and challenges, Kuwait Chapter of Arabian Journal of Business and Management Review, 1(7),

[18] Pallant, J. (2001). SPSS survival manual: A step by step guide to data analysis using SPSSfor windows. Maidenhead, UK: Open University Press.

[19] Rafil, I. B. (2008). Islamic Business Ethics.

[20] Sekaran, U. \& Bougie, R. (2010).Research methods for business: A skill building approaches (5th ed.). Chichester: John Willey \& Sons Ltd

[21] Shehu, A.Y. (2006). White Collar Crime and Its Impact on Foreign Relations of State, Unpublished MS.c Thesis Submitted to the Department of Political Science and International Relations, University of Abuja.

[22] Tabachnick, B.G. \& Fidell, L.S. (2007). Using multivariate statistics (5th ed.). Boston: Pearson Education Inc.

[23] Transparency International (TI) (2012).Corruption and Perception Index. TI Publication, London, pp 1.

[24] Transparency International (TI) (2013).Corruption and Perception Index. TI Publication, London. 